\title{
Uji Aktivitas Antibakteri dan Skrining Fitokimia Ekstrak Metanol Buah Hitam (H. monticola.) Asal Kabupaten Teluk Wondama
}

\section{Antibacterial Activity Test and Phytochemical Screening of Black Fruit Methanol Extract (H.Monticola) From Teluk Wondama}

\author{
Elsarina M. I. Siahaan ${ }^{1}$, Bimo B. Santoso ${ }^{2}$, Evelina Somar ${ }^{3}$, Maria Massora ${ }^{4}$ \\ Laboratorium Kimia dan Laboratorium Mikrobiologi FMIPA Universitas Papua, Manokwari \\ 98314 \\ Jalan Gunung Salju Amban, Manokwari \\ elsarinasiahaan69@gmail.com
}

\begin{abstract}
This study aimed to test the antibacterial activity and identify the secondary metabolite contect of the methanol extract Black Fruit (H. monticola). The black fruit extract was obtained through the maceration extraction method using methanol as a solvent. The result of phytocemical screening showed that the methanol extract of black fruit (H. monticola) contained high levels of tannins and saponins. Antibacterial activity test was carried out using the wall method with postive control of chloromphenicol and negative control with methanol. The result of antibacterial activity test against E. Coli bacteria showed strong activity with an inhibition zone diameter of 11 $\mathrm{mm}$ and B. Subtilis bacteria showed moderate activity with an inhibition zone with a diameter of 8 $\mathrm{mm}$.
\end{abstract}

Keywords : antibacterial, black fruit (H.monticola)

\section{PENDAhUluan}

Buah Hitam (H.monticola) atau biasa dikenal dengan sebutan "Piarawi" dalam bahasa Wandamen merupakan jenis tumbuhan asli Papua (endemik) dan salah satu dari 15 jenis Haplolobus yang berada di Papua, serta merupakan salah satu komunitas dari hutan hujan tropik dataran rendah, yang tumbuh dan menyebar pada daerah tanah, tanah berbatu sampai berbatu dengan ketinggian 10-500 meter dari permukaan laut (Lekitoo et.al, 2012). Tanaman Buah Hitam (H.monticola) atau Piarawi ini digunakan masyarakat Wondama sebagai bahan makanan adat, dimana buahnya dapat dimakan langsung atau dapat dicampurkan dengan sagu. Kandungan gizi buah hitam cukup tinggi: kadar protein 2,48 g, lemak $14,73 \mathrm{~g}$, dan vitamin C 277,45 mg. Tanaman ini juga biasanya disajikan sebagai bahan makanan tradisional dalam acara adat masyarakat Wondama seperti perkawinan, serah terima mas kawin, atau hari-hari keberuntungan masyarakat Wondama. (Somar E, 2014). Buahnya dicampur dengan aci sagu yang disebut "sagu buah hitam" dan dapat bertahan 2 bulan tanpa mengalami kerusakan sehingga diduga buah hitam mengandung pengawet alami seperti zat antibakteri, namun belum ada penelitian yang dilakukan terkait aktivitas antibakteri dari ekstrak buah hitam (H.monticola) sehingga pada penelitian ini dilakukan uji 
aktivitas antibakteri pada Buah Hitam (H.monticola).

\section{METODE}

\subsection{Waktu dan Tempat Penelitian}

Penelitian ini dilaksanakan kurang lebih selama 2 bulan yaitu dari bulan SeptemberOktober 2020. Pembuatan ekstrak dan skrining fitokimia di laboratorium Kimia Jurusan Kimia dan uji aktifitas antibakteri dilakukan di laboratorium Mikrobiologi Jurusan Biologi Fakultas Matematika dan Ilmu Pengetahuan Alam Universitas Papua, Manokwari.

\subsection{Alat dan Bahan}

Alat-alat yang digunakan dalam penelitian ini adalah: botol coklat, rotary evaporator,oven, kain serbet, timbangan analitik, seperangkat alat-alat gelas (tabung reaksi, gelas ukur $150 \mathrm{ml}$ dan $200 \mathrm{ml}$, gelas piala $50 \mathrm{ml}$ dan $100 \mathrm{ml}$, gelas arloji, labu takar ) ,hotplate, pipet gondok $10 \mathrm{ml}$, pipet tetes, ballfiler/propipet, termometer, corong gelas, batang pengaduk. Untuk uji aktivitas antibakteri alat yang digunakan adalah gelas beaker, oven, mikro pipet, alat suntik, cawan petri, kertas cakram, ose, pingset, hotplate, api bunsen, autoklaf, tabung reaksi, dan erlenmeyer

Bahan-bahan yang digunakan dalam penelitian adalah : sampel Buah Hitam (Haplolobus $s p$ ) metanol, $\mathrm{HCl} 2 \mathrm{~N}$, aquadest, pereaksi Mayer $\left(\mathrm{HgCl}_{2}\right.$ dan $\left.\mathrm{KI}\right)$, heksan, $\mathrm{CHCl}_{3}, \mathrm{Na}_{2} \mathrm{SO}_{4}$, Serbuk $\mathrm{Mg}$, pereaksi Wagner $\left(\mathrm{I}_{2}\right.$, KI). Pereaksi LibermannBurchard $\left(\mathrm{H}_{2} \mathrm{SO}_{4}, \quad \mathrm{CH}_{3} \mathrm{CO}_{2} \mathrm{H}, \quad\right.$ etanol $)$, $\mathrm{CH}_{3} \mathrm{CO}_{2} \mathrm{H}$ anh, $\mathrm{H}_{2} \mathrm{SO}_{4}$ pekat, $\mathrm{NaCl} 10 \%$, $\mathrm{FeCl}_{3} 1 \%$, preaksi dragon draff (bismuth nitrat). Sementara bahan yang digunakan untuk uji aktivitas bakteri adalah: bakteri Escherichia Coli (E.Coli), bakteri Basilus Subtilis, Nutrient Agar (NA), Natrium Broth (NB), kontrol positif (kertas cakram berisi kloromfenikol 0,1 gram didalam $100 \mathrm{ml}$ aquadest) dan untuk kontrol negatif dengan pelarut metanol.

\subsection{Prosedur Kerja}

\section{Preparasi Sampel}

Buah Hitam (H.monticola) yang telah matang dikeluarkan bijinya, kemudian dikeringkan. Setelah itu sampel dihaluskam menggunakan mortar dan dioven selama 24 jam pada suhu $40^{\circ} \mathrm{C}$.

\section{Pembuatan Ekstrak}

Sampel Buah Hitam (H.monticola) yang telah halus dimaserasi menggunakan metanol dengan perbandingan 1:2 selama 3 hari. Kemudian disaring. Proses maserasi dilakukan pengulangan sebanyak 3 kali. Hasil ekstrak yang diperoleh digabung menjadi satu lalu diuapkan dengan alat rotary evaporator dengan suhu $75^{\circ} \mathrm{C}$ (titik didih metanol) sehingga didapat ekstrak kental metanol. Ekstrak metanol yang diperoleh selanjutnya akan ditentukan kandungan fitokimia, dan uji aktivitas antibakteri.

\subsection{Skrining Fitokimia \\ 1. Uji Alkaloid}

$3 \mathrm{~mL}$ ekstrak ditambahkan $5 \mathrm{ml} \mathrm{HCl} 2$ $\mathrm{N}$ dan $6 \mathrm{~mL}$ aquades, dipanaskan menggunakan pemanas air selama 15 menit pada suhu $70^{\circ} \mathrm{C}$ kemudian didinginkan dan disaring. Filtrat yang diperoleh di bagi ke dalam 4 tabung reaksi. Tabung pertama diberi pereaksi mayer, tabung kedua diberi pereaksi Dragondorf, tabung ketiga diberi pereaksi Wagner, tabung keempat sebagai blanko. Jika terdapat endapan maka positif mengandung alkaloid. Pereaksi Mayer (+) jika terdapat endapan merah. Pereaksi Wagner (+) jika terdapat endapan merah. Pereaksi Wagner (+) jika terdapat endapan cokelat. Pereaksi Dragondroff (+) jika endapan berwarna cokelat putih.

\section{Uji Flavonoid}

$1 \mathrm{~mL}$ ekstrak ditambahkan dengan 5 $\mathrm{mL}$ etanol, kemudian dipanaskan selama 10 menit. Setelah itu didinginkan dan disaring. Filtrat dibagi ke dalam 3 tabung reaksi. Tabung pertama ditambahkan 3 tetes $\mathrm{H}_{2} \mathrm{SO}_{4}$ pekat. Jika terbentuk warna merah sampai jingga maka uji dikatakan positif 
mengandung flavonoid. Tabung kedua ditambahkan 0,5 $\mathrm{ml} \mathrm{HCl}$ pekat dan serbuk magnesium. Jika terjadi perubahan warna merah sampai ungu, hijau, atau biru muda maka uji dikatakan positif flavonoid. Tabung ketiga sebagai blanko.

\section{Uji Saponin}

Uji Busa, ekstrak ditambahkan $1 \mathrm{ml}$ aquades dikocok kemudian diamkan selama 30 menit. Hasil yang positif jika terbentuk buih yang tidak hilang selama 30 menit.

Uji Libermann-Burchard, ekstrak dicuci dengan heksan, kemudian diuapkan. Hasil residu ditambahkan dengan $2 \mathrm{ml}$ $\mathrm{CHCl}_{3}$, dan diaduk kemudian dilakukan dekantasi. Lapisan $\mathrm{CHCl}_{3}$ ditambahkan $\mathrm{Na}_{2} \mathrm{SO}_{4}$ kemudian disaring. Filtrat yang dihasilkan dibagi menjadi 2 bagian, satu bagian sebagai blanko sedangkan satu bagian lagi ditetesi dengan asam asam asetat anhidrat, dikocok kemudian ditambhkan $\mathrm{H}_{2} \mathrm{SO}_{4}$ pekat leawat dinding tabung (biru menjadi hijau, pink, merah dan ungu).

\section{Uji Tanin}

Sampel ditambahkan $3 \mathrm{~mL}$ aqauades panas sambil diaduk kemudian didinginkan. Setelah itu ditambahkan 5 tetes $\mathrm{NaCl}$ 10\% dan disaring. Filtrat dibagi dua bagian A dan B. Filtrat A digunakan sebagai blanko. Ke dalam filtrat B ditambahkan 3 tetes larutan garam gelatin. Kemudian diamati perubahan yang terjadi, jika terbentuk endapan menunjukkan positif tanin.

\subsection{Uji aktivitas antibakteri ekstrak Buah Hitam}

\section{Pembuatan Media}

Medium yang digunakan dalam penelitian ini adalah Medium Nutrient Agar (NA) dan Nutrient Broth (NB). Komposisi Medium NA dalam satu (1) liter aquadest adalah : ekstrak beef 3 gram, pepton 10 gram, dan agar 20 gram dan desterilisasi dengan autoklaf dengan suhu $121^{\circ} \mathrm{C}$ selama 15 menit pada tekanan 1 atm. Komposisi medium Natirum Broth dalam satu (1) liter aquadest adalah : ekstrak beef 3 gram, pepton 10 gramdan desterilisasi dengan autoklaf dengan suhu $121^{\circ} \mathrm{C}$ selama 15 menit pada tekanan 1 atm. Sebelum disterilkan, medium NB dipipet masing-masing sebanyak $7 \mathrm{ml}$ kedalam tabung reaksi. Komposisi bahan yang digunakan dihitung dengan menggunakan rumus sebagai berikut

$$
\text { Medium }=\frac{\text { Volume Medium }}{1000 \mathrm{ml}} \times \text { berat bahan }
$$

\section{Peremajaan Isolat Bakteri Uji}

Isolat bakteri uji yang akan digunakan dalam penelitian ini adalah bakteri E.coli (gram negatif ) dan bakteri B.subtilis (gram positif). Bakteri uji diremajakan terlebih dahulu dengan cara mengambil 1 ose isolat uji yang diinokulasikan ke dalam medium $\mathrm{NB}$ dan ditumbuhkan pada suhu $32^{\circ} \mathrm{C}$ selama $1 \times 24$ jam

\section{Uji aktivitas antibakteri Metode Sumuran}

Pengujian aktivias antibakteri atau daya hambat ektrak metanol buah hitam terhadap pertumbuhan bakteri E.coli dan B.subtilis dilakukan dengan metode difusi sumuran. Bakteri uji E.coli yang berumur 24 jam dimasukkan ke dalam cawan petri steril sebanyak $1 \mathrm{ml}$ dan dituangkan media NA sebanyak $15 \mathrm{ml}$, campuran ini dihomogenkan. Setelah campuran isolasi uji dam medium memadat, dibuat sumuran menggunakan tip steril yang berdiameter 6 $\mathrm{mm}$. Ekstrak metanol buah hitam, pelarut metanol (kontrol negatif), antibiotik kloromfenikol (kontrol positif) dipipet ke dalam setiap sumuran sebanyak 40 $\mu 1 /$ sumuran. Setelah itu, semua cawan petri tersebut pada suhu $37^{\circ} \mathrm{C}$ selama 24-72 jam. Zona hambat yang tampak pada setiap agar, kemudian diukur dengan menggunakan jangka sorong. Prosedur yang sama dilakukan terhadap bakteri uji B.subtilis. 


\section{III.HASIL DAN PEMBAHASAN}

3.1 Pembuatan Ekstrak Buah Hitam (H.monticola)

Pembuatan ekstrak buah hitam (H.monticola) dilakukan dengan cara 4 (empat) pengujian. Pada pengujian untuk preperasi sampel, pembuatan ekstrak dan skrining fitokimia dilakukan di Laboratorium Kimia sedangkan pengujian antibakteri dilakukan di laboratorium Mikrobiologi. Pengujian sampel buah hitam yang telah matang dikeluarkan bijinya, kemudian dikeringkan. Setelah itu sampel buah hitam dihaluskan menggunakan mortar dan dioven selama 24 jam pada suhu $40^{\circ} \mathrm{C}$ untuk mengurangi kadar air pada sampel.

Pada pengujian pembuatan ekstrak, sampel buah hitam yang telah halus dimaserasi menggunakan metanol dengan perbandingan 1:2 selama 3 hari. Proses maserasi merupakan perendaman sampel dengan pelarut organik yang digunakan pada suhu ruangan. Proses ini sangat menguntungkan dalam isolasi senyawa bahan alam karena melaui perendaman sampel tumbuhan akan terjadi pemecahan dinding dan membran sel akibat perbedaan tekanan antara di dalam dan diluar sel sehingga metabolit sekunder yang ada dalam sitoplasma akan terlarut. Kemudian sampel atau ekstrak buah hitam disaring. Total pelarut yang digunakan sebanyak $1325 \mathrm{ml}$ dengan rendemen ekstrak kental yang didapatkan sebesar 45,754 gram, ini berarti $26,60 \%$ senyawa yang larut dalam pelarut metanol dari keseluruhan senyawa yang terdapat dalam esktrak buah hitam (H.monticola).

Umumnya dalam proses ektraksi bahan alam, digunakan pelarut polar karena dapat menghasilkan rendemen yang lebih besar dibanding pelarut nonpolar. Pelarut yang digunakan dalam proses ekstraksi buah hitam adalah metanol. Hal ini dikarenakan metanol merupakan pelarut yang bersifat polar yang efektif digunakan dalam proses ektraksi komponen senyawa organik. Selain itu, metanol mampu mengikat senyawa yang bersifat polar, semipolar dan nonpolar sehingga hasil ekstrak yang diperoleh rendemennya tinggi.

Sebagian besar karbon, nitrogen, dan energi digunakan untuk menyusun molekulmolekul utama : (karbohidarat, lemak, protein, dan asam nukleat) yang disebut metabolit sekunder. Metabolit sekunder pada tumbuhan terjadi pada semua organ tumbuhan termasuk di akar, pucuk, daun bunga, buah, dan biji (Gutzeit \& Ludwig,2014). Metabolit sekunder pada tumbuhan memiliki beberapa fungsi yaitu: 1) pertahanan terhadap virus, bakteri, fungi; tumbuhan kompetitor dan yang paling penting adalah terhadap herbivora 2) atraktan (bau, warna, rasa untuk polinator dan hewan penyebar biji 3) perlindungan dari sinar UV dan penyimpanan-N. Jalur biosintetik metabolit sekunder berasal dari berbagai prukusor metabolisme primer. Prokursor adalah molekul yang digunakan oleh enzim biosintetik sebagai substrat dan dikonversi menjadi suatu produk. Produknya bisa berupa senyawa intermediet, jadi digunakan sebagai prekursor enzim biosintetik berikutnya, atau sebagai produk akhir dari reaksi tertentu. Dalam suatu skema reaksi yang kompleks, dengan banyak simpangan, suatu senyawa intermediet secara simultan juga merupakan prekursor untuk bagian lain dari jalur reaksi. Sebagai contoh, asam sikimat bisa menjadi senyawa intermediet untuk metabolisme asam amino dan juga sebagai prekursor untuk biosintesis metabolisme aromatik.

\subsection{Hasil Skrining Fitokimia Ekstrak Metanol}

Uji fitokimia pada penelitian ini merupakan uji pendahuluan untuk mengetahui secara kualitatif kandungan senyawa metabolit sekunder pada sampel buah hitam. Identifikasi kandungan kimia dalam ekstrak buah hitam dilakukan terhadap golongan senyawa alkaloid, flavanoid, tanin, dan saponin. Berikut ini adalah hasil skrining 
fitokimia ekstrak metanol buah hitam (H.monticola) dapat dilihat pada tabel 4.2

Tabel 3.1 Hasil skrining fitokimia ekstrak metanol pada Buah Hitam (H.monticola)

\begin{tabular}{|c|c|}
\hline Uji Fitokimia & Hasil Pengamatan \\
\hline Alkaloid & $\begin{array}{c}- \\
\text { (Pada ketiga pereaksi } \\
\text { tidak terdapat } \\
\text { endapan) }\end{array}$ \\
\hline Flavanoid & $\begin{array}{c}- \\
\text { (Pada ketiga tabung } \\
\text { tidak terjadi } \\
\text { perubahan warna) }\end{array}$ \\
\hline Tanin & $\begin{array}{c}+++ \\
\text { (Terjadi perubahan } \\
\text { warna hijau menjadi } \\
\text { hitam dan adanya } \\
\text { sedikit endapan) } \\
\end{array}$ \\
\hline Saponin & $\begin{array}{c}++ \\
\text { (Terdapat banyak } \\
\text { busa disisi-sisi tabung } \\
\text { dan adanya endapan) }\end{array}$ \\
\hline
\end{tabular}

Keterangan :

$\begin{array}{ll}- & : \text { Negatif } \\ +++ & : \text { Positif kuat }\end{array}$

Berdasarkan hasil pengujian menggunakan uji alkaloid dengan menggunakan pereaski Mayer, Wagner dan Dragondfaff. Pereaksi mayer memberikan hasil positif jika terdapat endapan merah, perekasi wagner memberikan hasil positif jika terdapat endapan cokelat, dan pereaksi dragondraff memberikan hasil positif jika endapan berwarna cokelat putih. Setelah dilakukan pengujian, dapat disimpulkan bahwa uji alkaloid yang dihasilkan adalah negatif (-) yaitu ditandai dengan ketiga tabung reaksi tidak adanya endapan yang terlihat.. Untuk hasil pengujian flavonoid menggunakan $\mathrm{H}_{2} \mathrm{SO}_{4}, \mathrm{HCl}$, dan serbuk magnesium. Jika ditambahkan dengan larutan $\mathrm{H}_{2} \mathrm{SO}_{4}$ memberikan hasil positif yaitu terbentuk warna merah sampai jingga sedangkan jika ditambahkan $\mathrm{HCl}$ dan serbuk magnesium maka terjadi perubahan warna merah sampai ungu, hijau, atau biru muda. Setelah dilakukan pengujian dapat disimpulkan bahwa hasil yang didapatkan dari ketiga tabung tersebut adalah negatif (-) yang ditandai dengan tidak terjadi perubahan warna.

Pengujian tanin dilakukan menggunakan larutan $\mathrm{NaCl}$ yang akan memberikan hasil positif jika terdapat endapan. Berdasarkan hasil pengamatan menunjukkan positif kuat (+++) ditandai dengan terjadi perubahan warna hijau menjadi hitam dan adanya sedikit endapan. Pada pengujian saponin menggunakan aquadest yang akan memberikan hasil positif jika terbentuk buih yang tidak hilang selama 30 menit. Setelah dilakukan pengujian dapat disimpulkan bahwa uji saponin juga menunjukkan positif kuat (+++) dengan ditandai terdapat banyak busa disisi-sisi tabung dan adanya endapan.

Metabolit sekunder merupakan biomolekul sebagai penemuan dan pengembangan obat-obat baru. (Atun,2008). Senyawa metabolit sekunder yang umum terdapat pada tanaman adalah : alkaloid, flavonoid, steroid, saponin, terpenoid, dan tanin (Harborne,1987). Salah satu tumbuhan yang menghasilkan senyawa metabolit sekunder adalah Buah Hitam (H.monticola), dimana senyawa yang terkandung yaitu tanin, dan saponin. Metabolit sekunder berupa molekul-molekul kecil, bersifat spesifik (tidak semua organisme mengandung senyawa sejenis), mempunyai struktur yang bervariasi, setiap senyawa memiliki fungsi atau peranan yang berbedabeda. Pada umumnya senyawa metabolit sekunder berfungsi untuk mempertahankan diri atau untuk mempertahankan eksistensinya di lingkungan tempatnya berada.

Adanya gugus fenol ditunjukkan dengan warna hijau kehitaman atau biru tua 
setelah ditambahkan dengan $\mathrm{FeCl}_{3}$, sehingga apabila uji fitokimia dengan $\mathrm{FeCl}_{3}$ memberikan hasil positif dimungkinkan dalam sampel terdapat senyawa fenol dan dimungkingkan salah satunya adalah tanin karena tanin merupakan polifenol. Hal ini diperkuat oleh (Harborne,1987) cara klasik untuk mendeteksi senyawa fenol sederhana yaitu menambahkan ekstrak dengan larutan $\mathrm{FeCl}_{3} 1 \%$ dalam air, yang menimbulkan warna hijau, merah, ungu, biru atau hitam yang kuat. Terbentuknya warna hijau kehitaman atau biru tinta pada ekstrak setelah ditambahkan dengan $\mathrm{FeCl}_{3}$ karena tanin akan membentuk senyawa kompleks dengan ion $\mathrm{Fe}^{3+}$. Berikut ini adalah gambar reaksi antara tanin dan $\mathrm{FeCl}_{3}$.

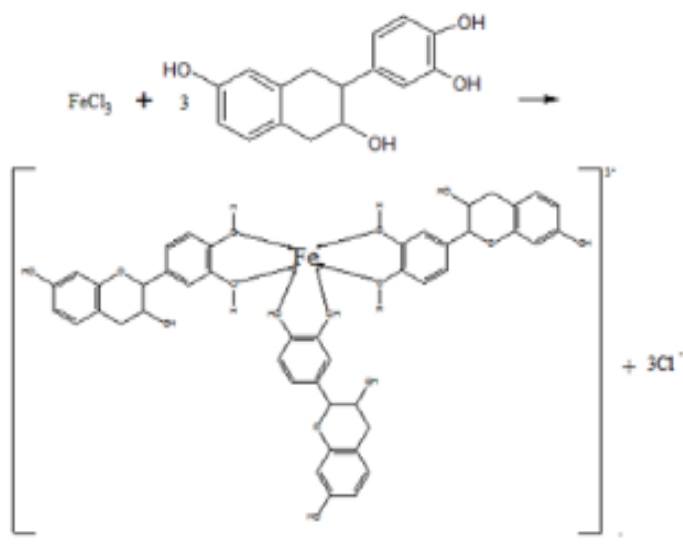

Gambar 3.1 reaksi santara tanin dan $\mathrm{FeCl}_{3}$

Saponin merupakan suatu glikosida dengan gugus hidroksil pada molekulnya dengan rumus $\mathrm{C}_{32} \mathrm{H}_{18} \mathrm{O}_{7}$. Saponin mempunyai sifat seperti sabun, ketika dilarutkan dalam air akan terbentuk busa atau buih, dimana guugus hidrofil dan hidrofob bertindak sebagai permukaan aktif dalam pembentukan busa. Terbentuknya busa menunjukkan adanya glikosida yang memiliki kemampuan membentuk buih dalam air yang terhidrolisis menjadi glukosa dan senyawa lainnya (Rusdi,1990). Terbentuknya busa menunjukkan adanya glikosida yang memiliki kemampuan membentuk buih dalam air yang terhidrolisis menjadi glukosa dan senyawa lainnya (Rusdi,1990).

Uji positif untuk saponin adalah dengan terbentuknya busa yang stabil. Saponin dapat larut dalam air karena adanya gugus hidrofil $(\mathrm{OH})$ yang dapat membentuk ikatan hidrogen dengan molekul air. Dari hasil pengujian saponin didapatkan hasil positif ditunjukkan dengan adanya busa yang stabil dan tidak hilang 30 menit. Pembentukan busa dapat terjadi karena saponin mempunyai dua sifat yang berlawanan pada strukturnya yaitu glikosida yang bersifat polar dan cincin steroid yang bersifat nonpolar. Sehingga jika dikocok dengan air maka hanya glikosida yang akan berikatan dengan air sedangkan steroidnya akan menolak air, hal inilah prinsip terjadinya pembentukan busa (Riawan,1990). Reaksi pembentukan busa pada uji saponin ditunjukkan pada gambar 4.2.
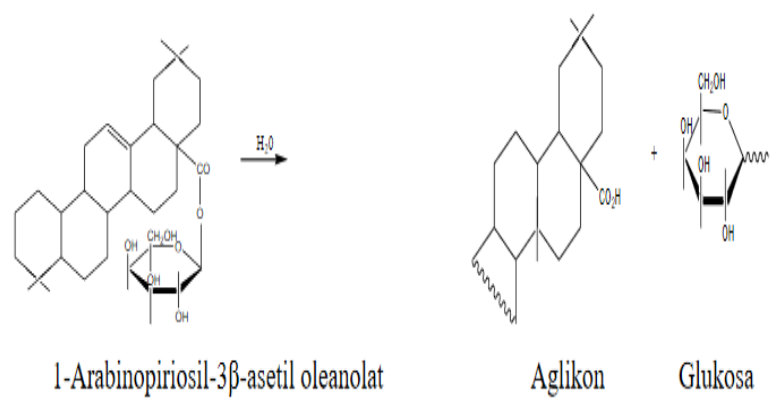

Gambar 3.2 Reaksi pembentukan busa pada uji saponin

\subsection{Uji Aktivitas Antibakteri}

Pengujian aktivitas antibakteri dilakukan dengan metode sumuran agar mengetahui diameter penghambat ekstrak terhadap bakteri uji yang tergolong bakteri patogen. Uji dilakukan dengan menggunakan fraksi dalam pelarut metanol. Kontrol positif yang digunakan uji aktivitas antibakteri pada kedua bakteri E.coli dan B.subtillis adalah antibiotik kloromfenikol dan kontrol negatifnya menggunakan pelarut metanol. 
Tabel 3.2 Diameter penghambatan bakteri uji terhadap ekstrak Buah Hitam (H.monticola)

\begin{tabular}{ccccc}
\hline & & \multicolumn{3}{c}{$\begin{array}{c}\text { Rata- rata diameter zona } \\
\text { bening (mm) }\end{array}$} \\
\cline { 2 - 5 } $\begin{array}{c}\text { Bakteri } \\
\text { Uji }\end{array}$ & $\begin{array}{c}\text { Waktu } \\
\text { inkubasi } \\
\text { (jam) }\end{array}$ & $\begin{array}{c}\text { Sampel } \\
\text { ekstrak } \\
\text { Buah } \\
\text { Hitam }\end{array}$ & $\begin{array}{c}\text { Kontrol } \\
\text { Positif }\end{array}$ & $\begin{array}{c}\text { Kontrol } \\
\text { negatif }\end{array}$ \\
\hline \multirow{3}{*}{ E.coli } & 24 & 11 & 9 & 5 \\
\cline { 2 - 5 } & 48 & 11 & 7 & 5 \\
\hline \multirow{2yyyy}{*}{ B. } & 72 & 11 & 7 & 5 \\
\cline { 2 - 5 } subtilis & 24 & 8,5 & 5 & 2 \\
\cline { 2 - 5 } & 48 & 8 & 5 & 2 \\
\hline
\end{tabular}

Hasil uji aktivitas antibakteri ektrak metanol buah hitam terhadap bakteri uji ditunjukkan dengan adanya zona bening disekitar sumuran yang mengindikasikan adanya aktivitas antibakteri dari ektrak metanol buah hitam terhadap bakteri uji. Semakin besar zona bening yang terbentuk maka semakin besar juga ekstrak dalam menghambat pertumbuhan bakteri. Kloromfenikol sebagai kontrol positif digunakan untuk pembanding melihat zat uji yang akan diteliti. Kloromfenikol dipilih karena merupakan antibiotik yang bersifat bakteriostatik dengan spektrum luas yang aktif terhadap bakteri gram negatif dan gram positif, serta mampu menghambat perlekatan asam amino dari bakteri. Metanol sebagai kontrol negatif digunakan untuk melihat apakah pelarut yang dinginkan memiliki pengaruh diameter zona hambat.

Berdasarkan, kriteria kekuatan antibakteri ekstrak metanol buah hitam termasuk untuk bakteri uji B.subtilis dalam kelompok daya hambat sedang (rata-rata diameter zona bening $8-8,5 \mathrm{~mm}$ ), dan untuk bakteri uji E.coli, masuk dalam zona hambat kuat (rata-rata diameter zona bening $11 \mathrm{~mm}$ ), namun berdasarkan spektrum kerjanya, ekstrak metanol buah hitam termasuk dalam kelompok spektrum luas karena mampu menghambat pertumbuhan kedua bakteri uji yang mewakili bakteri gram positif dan gram negatif. Pada gambar 4.2, bisa dilihat disisi kanan cawan petri adalah kloromfenikol sebagai kontrol positif, dibagian, kiri cawan petri adalah metanol sebagai kontrol negatifnya, dan pada bagian atas dan bawah adalah sampel dari buah hitam yang dilakukan pengulangan sebanyak 2(dua) kali.

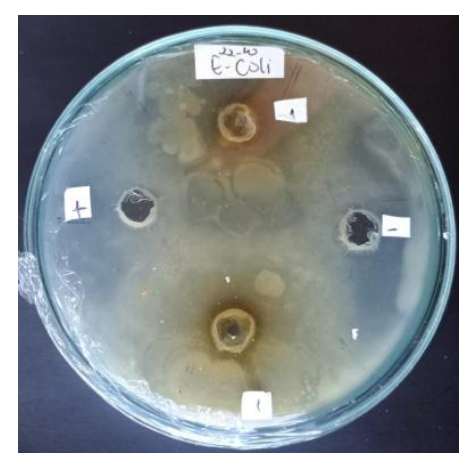

(a) E.coli

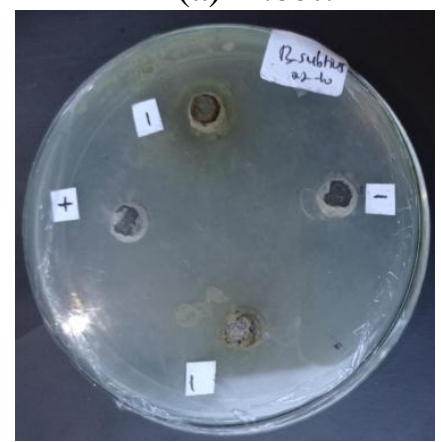

(b) B.subtilis

Gambar 3.3. Zona bening hasil uji ekstrak metanol buah hitam terhadap bakteri E.coli dan B.subtilis.

Senyawa antibakteri merupakan senyawa yang dapat mengganggu pertumbuhan atau metabolisme bakteri (Pelczar \& Chan, 1986). Berdasarkan sifat toksisitasnya, antibakteri dapat bersifat membunuh bakteri (bakterisidal) dan menghambat pertumbuhan bakteri (bakteriostatik). Antibakteri bakteriostatik hanya menghambat pertumbuhan bakteri dan tidak mematikan, sedangkan bakterisidal dapat membunuh bakteri. Bakteriostatik 
dapat bersifat bakteriosidal jika dalam konsentrasi yang tinggi. Berdasarkan hasil yang disajikan pada tabel 4.2, ekstrak metanol buah hitam bersifat bakterisidal karena dari hasil pengamatan jam ke-24 sampai dengan jam ke-72, tidak ada pengurangan diameter zona bening. Ini disebabkan karena ektrak metanol buah hitam (H.monticola) bisa mematikan bakteri uji.

Senyawa yang diduga berperan sebagai antibakteri ialah senyawa golongan flavonoid, saponin, terpenoid dan tanin. Dalam penelitian ini kemampuan Buah Hitam menghambat pertumbuhan bakteri uji karena Buah Hitam mengandung tanin dan saponin (Tabel 4.1). Mekanisme kerja tanin sebagai antibakteri yaitu menghambat enzim reverse transkriptase dan DNA topoisomerase sehingga sel bakteri tidak dapat terbentuk. Tanin mempunyai target pada polipeptida dinding sel sehingga pembentukan dinding sel terhambat. Hal ini menyebabkan terjadinya lisis pada sel bakteri karena tekanan osmotik sehingga sel bakteri akan mati (Sari F. P dan Sari N. M., 2010). Sedangkan mekanisme kerja saponin sebagai antibakteri adalah menurunkan tegangan permukaan sehingga mengakibatkan naiknya permeabilitas sel dan mengakibatkan senyawa intraseluler akan keluar (Cavalieri et al., 2005). Senyawa ini berdifusi melalui membran luar dan dinding sel yang rentan, lalu mengikat membran sitoplasma, mengganggu dan mengurangi kestabilan membran tersebut. Hal ini menyebabkan sitoplasma keluar dari intrasel menuju ekstrasel yang mengakibatkan kematian sel. Agen antimikroba yang mengganggu membran sitoplasma bersifat bakterisida (Cowan, 1999).

Flavonoid berperan dalam inhibisi pada sintesis DNA - RNA dengan interkalasi atau ikatan hidrogen dengan penumpukan basa asam nukleat, serta berperan dalam menghambat metabolisme energi. Senyawa ini akan mengganggu metabolisme energi dengan cara yang mirip dengan menghambat sistem respirasi, karena dibutuhkan energi yang cukup untuk penyerapan aktif berbagai metabolit dan untuk biosintesis makromolekul (Nuria et al., 2009). Namun berdasarkan hasil skrining fitokimia, Buah Hitam tidak mengandung Flavonoid.

\section{KESIMPULAN}

Hasil ekstraksi Buah Hitam (H.monticola) dengan metode maserasi menghasilkan rendemen ekstrak kental metanol sebanyak 45,754 gram (26,60\%). Hasil uji kandungan fitokimia ekstrak metanol buah hitam dari bakteri E.coli memberikan aktivitas kuat dengan diameter penghambat sebesar $11 \mathrm{~mm}$ dan bakteri B.subtilis memberikan aktivitas sedang dengan diameter penghambat sebesar $8 \mathrm{~mm}$

\section{V.SARAN}

Perlu dilakukan penelitian lebih lanjut dalam hal pemurnian ekstrak dan identifikasi senyawa aktif serta karakterisasi senyawa menggunakan spektroskopi dengan GC-MS dengan menggunakan pelarut lain.

\section{DAFTAR PUSTAKA}

Agoes, G. 2007. Teknologi Bahan Alam. Institut Teknologi Bandung (ITB) Press, Bandung

Aini, F.N., S. Sukamto, D. Wahyuni, R.G Suhesti, dan Q. Ayyunin. 2013. Penghambatan Pertumbuhan Colletotrichum Gloeosporioides Oleh Trichoderma Harzianum, Trichoderma Koningii, Bacillus Subtilis dan Pseudomonas Fluorescens. Jurnal Pelita Perkebunan 29(1): 44-52.

Aksara,R., J.A Weny., LaAlio M., 2013. Identifikasi Senyawa Alkaloid Dari Ekstrak Metanol Kulit Batang Mangga (Mangifera Indica L). Jurnal Entropi. Volume.VIII, nomor 1 
Arirahmayanti, I. 2019. Perbandingan Aktivitas AntiBakteri Ekstrak Etanol Kunyit (Curcuma longa) dan Bawang Putih (Allium sativum) Terhadap Eschorichia coli ATCC8739. Jurnal Merdika Udaya. Vol.8, nomor 3. ISSN: 2597-8012

Atun. 2008. Pemanfaatan Bahan Alam Bumi Indonesia Menuju Riset Yang Berkualitas Internasional. https://www.google.co.id. Diakses: 20 Februari 2013

[BAPPENAS]. 1993. Badan Perencana Pembangunan Nasional. Biodiversity Action Plan for Indonesia. Jakarta: BAPPENAS.

B, Santoso., Ibrahim, A., Situmeang, B., 2017. Analisis dan Identifikasi Senyawa Saponin Dari Daun Bidara (Zhizipus Mauritania L). Jurnal Itekimia. Vol.2,nomor 1. ISSN :2548-947

Bobbarala, V. 2012. Antimicrobial Agents. Croatia: Intech

Cavalieri, S.J., I.D. Rankin., R.J. Harbeck., R.S. Sautter., Y.S. McCarter., S.E. Sharp., J.H. Ortez., dan C.A. Spiegel., 2005. Manual of Antimicrobial Susceptibility Testing. American Society for Microbiology: USA

Cholifah, Nur. 2017. Pemanfaatan Daun Putih dan Daun Pandan Sebagai Pengawet Alami Tahu Ditinjau dari Masa Simpan dan Tingkat Kesukaan. Jurnal Kesehatan Lingkungan. Vol.9, nomor 1. Poltekkes Kemenkes, Yogyakarta.

Cowan, M.M. 1999. Plant Products as Antimicrobial Agents. Clinical Microbiology Reviews. 12: 564 - 582.

Davis, W.W . and Stout, T.R. 1971. Disc plate methods of microbiological antibiotic assay. J. Microbiology. (4): 659-665
Dwidjoseputro, D. 2003. Dasar-Dasar Mikrobiologi. Djambatan . Jakarta

Ergina., Nurhayati S., Puspitasari I.D., 2014. Uji Kualitatif Senyawa Metabolit Sekunder Pada Daun Palado (Agave angustifolia) Yang Diekstraksi Dengan Pelarut Air dan Metanol : J.Akad.Kim.3(3). ISSN 2302-6030

Fatisa, Y. 2013. Daya Antibakteri Ekstrak Kulit dan Biji Buah Pulasan (Naphelium Mutabik) Terhadap Staphyloccoccus aurens dan Echorichia coli Secara In Vitro. Jurnal Peternakan. Vol.10, nomor 1. Fakultas Pendidikan, Jurusan Pendidikan Kimia : Universitas Islam Negeri Syarif Kasim, Riau

Febrianasari, F. 2018. Skripsi : Uji Aktivitas Antibakteri Ekstrak Daun Kurinyu (Chromolaena odorata) Terhadap Staphylococcus aurens. Universitas Sanata Dharma, Yogyakarta

Forbes, B.A., Sahm D.F.,Weissfeld A.S. 2007. Bailey \& Scott's Diagnostic Microbiology $12^{\text {th }}$ Edition. Missouri

Gutzeit, H.O., Muller J.L. 2014. Book: Plant Natural Product: Synthesis, Biological Functions, and Practical Applications

Harborne,J.B. 1987. Metode Fitokimia Penentuan Cara Modern Menganalisis Tumbuhan. ITB:Bandung

Hargono, A. 2008. Pembuatan Khitosan dari Limbah Cangkang Udang Serta Aplikasinya Dalam Mereduksi Kolestrol Lemak Kambing. Jurnal : Reaktor Vol.12, Nomor 1 : 53-57. Jurusan Kimia Fakultas Teknik UNDIP, Semarang.

Hartati, S., Darmadji P., Parnoto,Y., 2015. Penggunaan Asap Cair Tempurung Kelapa Untuk Menurunkan Kadar Timbal (Pb) Pada Biji Kedelai (Glycine Max). Jurnal Argitech. 
Universitas Gadjah Mada, Yogyakarta. Vol.35, Nomor 3

Hatmanti. 2000. Pengenalan Bacillus Spp. Jurnal : Oseana. Volume XXV, Nomor.1 : 31-41 (sumber : www.oseanografi.lipi.go.id)

Hendrayana, M.. 2017. Sripsi : Identifikasi dan Diagnosis Infeksi Bakteri Salmonella Typhi. Program Studi Pendidikan Dokter, Fakultas Kedokteran. Universitas Udayana, Bali

Hidayah, N. 2016. Pemanfaatan Senyawa Metabolit Sekunder Tanaman (Tannin dan Sponin) Dalam Mengurasi Emisi Metan Ternak Ruminansia. Junal Sains Peternakan Indonesia. Universitas Muhammidiyah Bengkulu, Bengkulu. Vol.11, No 2

Jayanegara, A. and A Sofyan, 2008. Penentuan Aktivitas Biologis Tanin Beberapa Hijauan Secara In Vitro Menggunakan "Hohenheim Gas Test" Dengan Polietilen Glikol Sebagai Determinan. Media Peternakan 31(1):44-52

Kapitan, L. 2017. Aktivitas Antimikroba Ekstrak Laos Putih (Alpina Galangas) Terhadap Bakteri Eschericia Coli dan Salmonella Sp. Jurnal Info Kesehatan. Vol.15 Nomor 1. ISSN: 0216-504

Karimela, E. 2017. Karakteristik S.aurens yang Diisolasi dari Ikan Asap Pinekuhe Hasil Olahan Tradisional Kabupaten Sangihe. Jurnal Pengolahan Hasil Perikanan Indonesia (JPHPI) 2017. Vol.20, nomor 1

Kusmana, C., Hikmat A., 2015. Keanekaragaman Hayati Flora di Indonesia. Jurnal Pengelolaan Sumberdaya Alam dan Lingkungan. Vol.5, Nomor 2. ISSN-24605824
Lekitoo, K., Batorinding E., Dimomonmau P.A., Rumbiak, W.F., Heatubun C.D., Lekitoo H.Y., 2012. Re-diversifikasi Pangan di Tanah Papua Bagian-I. Pemanfaatan Enam Jenis Tumbuhan Hutan Penghasil Buah Sebagai Sumber Bahan Pangan di Tanah Papua. Kementrian Kehutanan Badan Penelitian dan Pengembangan Kehutanan.

Leon, L.D., M.R. Lopez., dan L Moujir., 2010. Antibacterial Properties of Zeylasterone a Triterpenoid Isolated from Maytenus blepharacles against Staphylococcus aureus. Microbiological Research: 12: $2-10$

Lestari, I. 2017. Skripsi: Identifikasi dan Diagnosis Infeksi Bakteri Salmonella typhi. Program Studi Pendidikan Dokter, Fakultas Kedokteran Universitas Udaya, Denpasar

Lisdawati.,et al. 2007. Isolasi dan Elusidasi Struktur Senyawa Lignam Dan Asamlemak Dari Ekstrak Daging Buah Phaleria Macrocarpa. Jurnal dan Bulletin Penelitian Kesehatan; Puslitbang Biomedis dan Farmasi Badan Litbangkes

Listari, Y. 2009. Efektifitas Penggunaas Metode Pengujian Antibiotik Isolat Streptomyces Dari Rizofer Familia Poaceae terhadap Eschericia Coli. Skripsi. Surakarta: Fakultas Keguruan dan Ilmu Pendidikan Universitas Muhammadiyah

Maburoh, A. 2015. Skripsi: Uji Aktivitas Antioksida Ekstrak Tanin Dari Daun Rumput $B a m b u$. Universitas Islam Negeri Maulana Malik Ibrahim, Malang

Mamuaja, C., Lumoindong F. 2017. Aktivitas Antimikorba Ekstrak Biji Kluwek (Pangium Edule) Sebagai Bahan Pengawet Alami Bakso Ikan Tuna. Jurnal Hasil Perikanan Indonesia (JPHPI) 2017 . Volume.20 Nomor 3 
Manuhutu, E. 2011. Efektivitas Biji Pangi (Pangium Edule Reinw) Sebagai Bahan Pengawet Alami Terhadap Beberapa Sifat Mutu dan Masa Simpan Ikan Cakalang (Katsuwonus pelamis). Tesis Ilmu Pangan, Pascasarjana. UNSRAT, Manado

Maulinda, Dewi. 2010. Skripsi: Ekstraksi Antioksidan (Likopen) Dari Buah Tomat Dengan Menggunakan Solven Campuran NHeksana, Aseton, dan Etanol. Universitas Diponegoro, Semarang

Mukhriani. 2014. Esktraksi, Pemisahan Senyawa, dan Identifikasi Senyawa Aktif: Jurnal Kesehatan. Program Studi Farmasi Fakultas Ilmu Kesehatan UIN Alauddin, Makassar. Volume.VII. No. 2

Nurhan, FA. 2015. Artikel AntiBakteri dan Anti Mikroba Dalam Menghambat Pertumbuhan Bakteri Staphylococcus Aureus, Escherichia Coli, dan Salmonella typhi. Pendidikan Fisika Universitas Negeri Jakarta

Nurhayati,L.S., Yadhiyanti N., Hidayatulloh A., 2020. Perbandingan Pengujian Aktivitas Antibakteri Starter Yogurt dengan Metode Difusi Sumuran dan Metode Difusi Cakram. Jurnal Teknologi Hasil Peternakan. Vol.1. No2 ; 41-26.

Nuria, M.C., A Faizatun., Sumantri., 2009. Uji Antibakteri Ekstrak Etanol Daun Jarak Pagar ( Jatropha cuircas L) terhadap Bakteri Staphylococcus aureus ATCC 25923, Escherichia coli ATCC 25922, dan Salmonella typhi ATCC 1408. Jurnal Ilmu Ilmu Pertanian. 5: $26-37$

Nur Iman, Muhammad. 2009. Skripsi: Aktivitas Antibakteri Ekstrak Metahnol Bunga Pepaya Jantan (Carica papaya L) Terhadap Escherichia coli dan Staphylococcus aureus multiresisten antibiotic. Fakultas Farmasi Universitas Surakarta

Patra, A. K.and J. Saxena. 2010. A New Perspective On The Use Of Plant Secondary Metabolites To Inhibit Methanogenesis In The Rumen. Journal Phytochemistry. 71: 1198- 1222

Pelczar, M. J., \& Chan, E. S. C. 1988. Buku : Dasar-Dasar Mikrobiologi (Edisi ke-2). Terjemahan Ratna Siri Hadioetomo, Teja Imas, S. Sutami, Sri Lestari. Jakarta: Universitas Indonesia

Pratiwi. 2014. Skripsi : Skrining Uji Efek Antimitosis Ekstrak Daun 'Botto-Botto' (Chloromolaena odorara. L.) Menggunakan Sel Telur BuluBabi (Tripneustus gratilla L.). Fakultas Ilmu Kesehatan: Universitas Islam Negeri Alauddin, Makassar

Pratiwi, M. 2019. Skripsi : Aktivitas Antibakteri Jambu Wer (Prunus persica (L.) Batsch Terhadap Pertumbuhan Bakteri Staphyloccus aurens. Jurusan Farmasi Universitas Islam Negeri Maulana Malik Ibrahim Malang, Malang

Prayoga, E. 2013. Skripsi : Perbandingan Efek Ekstrak Daun Sirih Hijau (Piper Betle L) dengan Metode Difusi Disk dan Sumuran Terhadap Pertumbuhan Bakteri Staphylococcus aurens. Fakultas Kedokteran dan Ilmu Kesehatan. Universitas Negeri Syarif Hidayatullah, Jakarta

Radji, Maksum. 2011. Mikrobiologi. Buku Kedokteran ECG. Jakarta.

Rini, A., Suprianto., Rahmatan H., 2017. Skrining Fitokimia dan Uji Antibakteri Ekstrak Etanol Buah Kawista (Limonia acidissima L.) dari Daerah Kabupaten Aceh Besar Terhadap Bakteri Escherichia Coli. Jurnal Ilmiah Mahasiswa Fakultas Keguruan 
dan Ilmu Pendidikan Unsyiah. Vol.2 Nomor 1

Riawan, 1990. Kimia Organik: Bina Rupa Aksara: Jakarta

Robinson, T. 1995. Kandungan Senyawa Organik Tumbuhan Tinggi Diterjemahkan oleh Prof.Dr. Kosasih Padmawinata ITB, Bandung

Rusdi. 1990. Tetumbuhan Sebagai Sumber Bahan Obat. Padang: Pusat Penelitian Universitas Andalas

Rutdianti., Kartika R.,Simanjuntak P., 2017. Isolasi dan Identifikasi Senyawa Kimia Terpenoid Dari Isolat Etil Asetat Daun Ekaliptus (Eucalypus deglupta Blume). Prosiding Seminar Nasional Kimia FMIPA Unmul, Kalimantan. ISBN 978-602-509420-0

Sari, F.P., dan S. M. Sari. 2011. Skripsi: Ekstraksi Zat Aktif Antimikroba dari Tanaman Yodium (Jatropha multifida Linn) sebgai Bahan Baku Alternatif Antibiotik Alami : Jurusan Teknik Kimia, Fakultas Teknik. Universitas Diponegoro, Semarang

Screen Paper. 2017. Artikel Penyebaran Buah Hitam (Haplolobus.cf. monticola Husson)

Septiana, Eris., Simanjuntak P., 2016. Aktivitas Penghambatan Bakteri Pembentuk Histamin dan AntiOksidan Kapang Endofit Kunyit Sebagai Pengawet Alami. Jurnal Biopropal Industri. Pusat Penelitian Bioteknologi, Bogor. Vol.7 Nomor 1

Setyowati,H., Zharfa H.H., Angela I.F., KS Joe., Muawanah., 2013. Skripsi: Isolasi dan Standarisasi Bahan Alam Gasc Chromatography- mass spectrometry GS$M S$. Sekolah Tinggi Ilmu Farmasi, Yayasan Farmasi, Semarang
Simaremare, Eva. 2014. Skrining Fitokimia Ekstrak Etanol Daun Gatal (Laportea decumana (Roxb.) Wedd). Jurnal : Pharmacy. ISSN 1693-3591, Vol.11.No 01. Program Studi Farmasi Jurusan Biologi Fakultas MIPA Universitas Cendrawasih, Jayapura

Steja, Aji. 2018. Skripsi: Identifikasi Senyawa Metabolit Sekunder Pada Daun Durian (duriozibethinus Murr) Progam Studi Biologi, Fakultas Biologi Universitas Medan Area, Medan

Soesanto, L. 2008. Pengantar Pengendalian Hayati Penyakit Tanaman, Suplemen ke Gulma dan Nematoda. Rajawali Pers. 573 p.

Somar, E. 2014. Pengaruh Faktor Abiotik Terhadap Kadar Tanin Daun Buah Hitam (Haplolobus cf, monticola Husson) asal Kabupaten Teluk Wondama. Thesis Program Pascasarjana Universitas Papua, Manokwari

S, Wulandari. 2015. Artikel: Hasil dan Pembahasan Proses Refluk dan Hasil Ekstraksi : digilib.uns.ac.id

Toja, Y., Suprayitno E, Aulanni'am, Yanuar U., 2020. In Silico Potential Black Fruit Seeds (Haplolobus Monticola) Wondama Local Plant West Papua Barat as Antibacterial Areomonas hydrophila. Journal of BioSciences: 14, 7125-7131

Ungirwalu, A. 2016. Pengelolaan Adaptif Pemanfaatan Buah Hitam (Haplolobus monticule blumea Etnis Wandeman-Papua (Adaptive Management Utilization of Black Fruit (Haplolobus monticule blumea) Ethnic Wandamen-Papua). Jurnal Manusia dan Lingkungan. Volume.23 Nomor 2

Yatno., Murni M., Nelwida., Yani E N., 2015. Kandungan Asam Sianida, Bahan Kering dan Bahan Organik Tepung Biji 
Karet Hasil Pengukusan. Jurnal Ilmu-Ilmu Peternakan. Vol.XVIII No 2

Zikra, Wahyu. 2018. Identifikasi Bakteri Escherichia coli (E.coli) Pada Air Minum di Rumah Makan dan Cafe di Kelurahan Jati Serta Jati Baru Kota Padang. Jurnal Kesehatan Andalas 7(2) 